\title{
Evaluation of the usefulness of antymüllerian hormone and inhibin B as markers of ovarian activity in patients with Turner syndrome - preliminary results
}

Ocena przydatności oznaczeń stężeń hormonu antymüllerowskiego i inhibny B jako markerów czynności jajników u pacjentek z zespołem Turnera - wyniki wstępne

\author{
Anna Ruszała, Małgorzata Wójcik, Jerzy Starzyk
}

Department of Pediatric and Adolescent Endocrinology, Jagiellonian University Collegium Medicum, Krakow, Poland

Department of Pediatric and Adolescent Endocrinology, Uniwersytecki Szpital Dziecięcy w Krakowie, Poland

Presented at $58^{\text {th }}$ European Society of Pediatric Endocrinology Meeting (19-21 September, Vienna, Austria, poster session) and at the Polish Pediatric Endocrinology and Diabetology Meeting (3-5 October 2019, Lublin, Poland).

\begin{abstract}
Introduction: Spontaneous puberty occurs in 30\% of patients with Turner Syndrome. Its absence is an indication for hormone replacement therapy (HRT). No reliable markers of spontaneous puberty have been defined to date.

Aim of the study: To evaluate the usefulness of antymüllerian hormone (AMH) and inhibin B assessment in predicting ovarian function and spontaneous puberty in girls with TS.

Material and methods: The study included 35 TS patients treated with human recombinant growth hormone (rhGH). Gonadal axis function parameters (LH, FSH and estradiol) were evaluated at the age of physiological puberty (10-12 years, mean 10.5 years), before introduction of HRT. Additionally $\mathrm{AMH}$ and inhibin B levels were assessed. In follow up patients were divided into 2 groups: with (SP) and without (WP) spontaneous puberty. Spontaneous puberty was defined as Tanner stage 2 or higher breast development. Results: WP patients were observed until the mean age of 16y. SP occurred in 16 patients (mean age 10 years). Patients with SP presented with significantly lower mean FSH level $(1.14-91.1 \mathrm{mlU} / \mathrm{ml}$, mean $\mathrm{mlU} / \mathrm{ml} 24.5 \mathrm{vs} .7 .7-196.4 \mathrm{mlU} / \mathrm{ml}, \mathrm{mean} 66.5 \mathrm{mIU} / \mathrm{ml}$, $p=0.002)$, higher mean estradiol (10.5-68.8 pg/ml, mean $28.4 \mathrm{pg} / \mathrm{ml} v \mathrm{vs} .6 .1-26.0 \mathrm{pg} / \mathrm{ml}$, mean 14.9 pg/ml, $p=0.005)$, AMH $(0.0-3.11 \mathrm{ng} / \mathrm{ml}$, mean $0.8 \mathrm{ng} / \mathrm{ml} \mathrm{vs.} 0.0-0.002 \mathrm{ng} / \mathrm{ml}$, mean $0.003 \mathrm{ng} / \mathrm{ml}, p=0.001)$ and inhibin B $(0.0-110.0 \mathrm{pg} / \mathrm{ml}, \mathrm{mean} 29.1 \mathrm{pg} / \mathrm{ml}$ vs. $0.0-11.0 \mathrm{pg} / \mathrm{ml}$, mean $1.06 \mathrm{pg} / \mathrm{ml}, p=0.026)$ levels. In three SP patients without elevated FSH level (FSH < $35 \mathrm{mlU} / \mathrm{ml})$ we found zero concentration levels of AMH and inhibin B. SP patients had mosaic (non 45,X) karyotype in $87.5 \%$ and WP patients only in $47 \%$.

Conclusions: $\mathrm{AMH}$ and inhibin B assessment may be a valuable complement to the diagnosis of ovarian function in patients with TS. Low levels of these parameters may indicate a risk of ovarian failure even in patients with spontaneous puberty and without hypergonadotropic hypogonadism.
\end{abstract}

\section{Key words:}

Turner syndrome, hypogonadism, puberty, $\mathrm{AMH}$, inhibin B.

\section{Streszczenie}

Wprowadzenie: Samoistne dojrzewanie występuje u 30\% pacjentek z zespołem Turnera (ZT), a jego brak jest wskazaniem do rozpoczęcia hormonalnej terapii zastępczej (HRT). Dotychczas nie określono wiarygodnych markerów określających prawdopodobieństwo wystąpienia samoistnego dojrzewania w tej grupie pacjentek.

Cel pracy: Ocena przydatności oznaczeń stężeń hormonu antymüllerowskiego i inhibny B jako markerów czynności jajników i predyktorów wystąpienia samoistnego dojrzewania u pacjentek z ZT.

Materiał i metody: Do badania włączono 35 pacjentek z ZT leczonych ludzkim rekombinowanym hormonem wzrostu w wieku fizjologicznego dojrzewania płciowego (10-12 lat, średni wiek 10,5 roku). Przed wprowadzeniem HRT oceniono oś gonadalną (LH, FSH, estradiol). Dodatkowo oznaczono stężenie AMH i inhibiny B. Podczas obserwacji pacjentki podzielono na dwie grupy: z samoistnym początkiem dojrzewania (SP) lub bez (WP). Samoistne dojrzewanie zdefiniowano jako rozwój piersi oceniony na stopień II lub wyższe w skali Tannera. 
Wyniki: Pacjentki z grupy WP pozostawały w obserwacji do średniego wieku 16 lat. Samoistny początek dojrzewania wystąpił u 16 pacjentek (średni wiek 10 lat). U pacjentek z grupy SP stwierdzono istotnie mniejsze stężenia FSH (1,14-91,1 mlU/ml, śr. $24,5 \mathrm{mlU} / \mathrm{ml} v s \mathbf{7 , 7 - 1 9 6 , 4} \mathrm{mlU} / \mathrm{ml}$, śr. $66,5 \mathrm{mlU} / \mathrm{ml}, p=0,002)$, większe stężenia estradiolu $(10,5-68,8 \mathrm{pg} / \mathrm{ml}$, śr. 28,4 pg/ml vs 6,1-26,0 pg/ml, śr. 14,9 pg/ml, $p=0,005)$, AMH (0,0-3,11 ng/ml, śr. 0,8 vs 0,0-0,002 ng/ml, śr. 0,003 ng/ml, p = 0,001) i inhibiny B $(0,0-110,0$ pg/ml, śr. 29,1 pg/ml vs 0,0-11,0 pg/ml, śr. 1,06 pg/ml, $p=0,026)$. U trzech pacjentek z grupy SP bez zwiększonego stężenia FSH $(\mathrm{FSH}<35 \mathrm{mlU} / \mathrm{ml}$ ) stwierdzono zerowe stężenia AMH i inhibiny B. Kariotyp mozaikowy (nie 45,X) stwierdzono u 87,5\% pacjentek z grupy SP i tylko u 47\% pacjentek z grupy WP.

Wnioski: Ocena stężeń AMH i inhibiny B może być wnieść dodatkową wartość podczas oceny funkcji jajników u pacjentek z ZT. Małe stężenia tych markerów mogą wskazywać na ryzyko niewydolności jajników nawet u pacjentek, które rozpoczęły dojrzewanie samoistnie i u których nie stwierdzono hipogonadyzmu hipergonadotropowego.

\section{Słowa kluczowe:}

zespół Turnera, hipogonadyzm, dojrzewanie, $\mathrm{AMH}$, inhibina B.

\section{Introduction}

Primary ovarian insufficiency means diminished functional activity of ovaries when defect is inherent within the gonads. One of the chromosomal abnormalities which is characterized by primary ovarian failure is Turner syndrome (TS). Although TS is in most patients associated with pubertal delay or failure and infertility, hypogonadism may occur at different age and clinically manifest as late or absent puberty, primary or secondary amenorrhea $[1,2]$. According to literature up to $30 \%$ of TS patients present with spontaneous pubertal development, $2-5 \%$ have regular menstrual cycles and $2 \%$ may get pregnant spontaneously [3]. As an ovarian insufficiency in TS patients is caused by accelerated loss of follicles that may start already into fetal life, it is important to identify right patients and time point for potential cryopreservation of ovarian tissue before follicles begin to disappear [4-6]. Moreover, estrogens are secreted from the healthy ovaries already in the prepubertal period and they seem to improve cognition and bone mineral density, optimize response to growth hormone treatment and bring some beneficial metabolic effect [7-14]. Gonadal axis in prepubertal children with ZT is difficult to be diagnosed, because it is centrally inhibited [15]. In that age, there is an overlap of the gonadotropin levels values between healthy girls and TS patients, therefore they may not reflect ovarian reserve in this period of life [15-17]. Some authors tried to define cut off value of serum FSH concentration in prepubertal girls with TS as an index for predicting spontaneous puberty and menarche, but to date there are no concrete guidelines in this field $[18,19]$. To date no reliable markers of spontaneous puberty have been defined. Novel candidates for ovarian function markers in TS patients are: Antymüllerian hormone $(\mathrm{AMH})$ and inhibin $\mathrm{B}$, that are secreted from developing follicles and have been found to positively correlate with antral follicle count [20]. It is believed that serum $\mathrm{AMH}$ and inhibin $\mathrm{B}$ levels reflects ovarian reserve independent from the hypothalamo-pituitary-gonadal axis. Moreover the decline in serum $\mathrm{AMH}$ levels precedes the changes in another markers for ovarian reserve (FSH, estradiol and inhibin B) [21, 22].

\section{Aim}

The present study aimed to evaluate the usefulness of $\mathrm{AMH}$ and inhibin B assessment in predicting ovarian function and spontaneous puberty in patients with TS.

\section{Material and methods}

The study conducted in the Department of Pediatric and Adolescent Endocrinology in Children's University Hospital in Krakow included 35 girls with TS (12 with monosomic karyotype $[45, X]$ and 23 with non-monosomic karyotype [non 45, X]) treated with $\mathrm{rhGH}$. Evaluation of gonadal axis function was performed at the age of physiological puberty (10-12 years, mean 10.5 years), before introduction of hormonal replacement therapy (HRT). Additionally $\mathrm{AMH}$ and inhibin B levels were assessed. In follow up patients were divided into 2 groups: with spontaneous puberty (SP) and without (WP). Spontaneous puberty was defined as Tanner stage 2 or higher breast development. In patients without spontaneous puberty induction of puberty using oral estrogen (Estrofem mite Novo Nordisk pills containing $1 \mathrm{mg}$ of $17 \beta$-estradiol) was started in accordance with present standards after the age of 12 .

Serum FSH and LH levels were measured by chemiluminometric assay with an ADVIA CENTAUR XPT machine. Serum estradiol was measured with radioimmunoassay. Serum AMH was measured by electrochemiluminescence immunoassay (ECLIA) with a COBAS machine. Serum Inhibin B was measured by enzyme-linked immunosorbent assay (ELISA) with an EUROIMMUN analyzer. Karyotypes results were obtained from patients records. All karyotyping analysis was performed using lymphocyte cultures.

To compare the two sets of data, the Student's t test or twosided Mann-Whitney $U$ test was used. For a correlation analysis, the correlation coefficient $(R)$ and regression analysis were used. The purpose of determining the odds ratio $(\mathrm{OR})$ was to use the logistic regression analysis. Statistically significant results were assumed for which the probability value was less than 0.05 . 


\section{Results}

Patients without spontaneous puberty were observed until the mean age of 16 years. Spontaneous puberty occurred in 16 patients at the mean age of 10 years (9-12 years old). Patients with SP presented with significantly lower mean FSH level (1.14-91.1 $\mathrm{mlU} / \mathrm{ml}$, mean value $24.5 \mathrm{mlU} / \mathrm{ml}$ vs. 7.7-196.4 $\mathrm{mlU} / \mathrm{ml}$, mean value $66.5 \mathrm{mlU} / \mathrm{ml}, p=0.002)$, significantly higher mean estradiol (10.5-68.8 pg/ml, mean value $28.4 \mathrm{pg} / \mathrm{ml}$ vs. $6.1-26.0 \mathrm{pg} / \mathrm{ml}$, mean value $14.9 \mathrm{pg} / \mathrm{ml}$, $p=0.005), \mathrm{AMH}(0.0-3.11 \mathrm{ng} / \mathrm{ml}$, mean value $0.8 \mathrm{ng} / \mathrm{ml}$ vs. $0.0-0.002 \mathrm{ng} / \mathrm{ml}$, mean value $0.003 \mathrm{ng} / \mathrm{ml}, \mathrm{p}=0.001$ ) and inhibin B (0.0-110.0 pg/ml, mean value $29.1 \mathrm{pg} / \mathrm{ml}$ vs. $0.0-11.0 \mathrm{pg} / \mathrm{ml}$, mean value $1.06 \mathrm{pg} / \mathrm{ml}, p=0.026$ ) levels. Interestingly, in three SP patients with not elevated FSH level ( $\mathrm{FSH}<35 \mathrm{mlU} / \mathrm{ml}$ ) we found zero concentration levels of $\mathrm{AMH}$ and inhibin B. Patients with SP had mosaic (non 45, X) karyotype in $87.5 \%(14 / 16)$ and monosomy $(45, X)$ only in $12.5 \%$ $(2 / 16)$. Patients without spontaneous puberty had mosaic (non $45, \mathrm{X})$ karyotype in $47 \%(9 / 19)$ and monosomy in 53\% (10/19).

\section{Discussion}

Primary hypogonadism is stated as one of the main features of TS. Although most patients demand estrogen replacement therapy, secretion of endogenous estrogens may be sufficient in some patients to finish the process of puberty, maintain menstrual cycles and even lead to not assisted pregnancy [3].

In our study $45 \%$ of TS patients presented with spontaneous puberty before the age of 12 . Our results remain in accordance with another studies with the frequency of spontaneous puberty in TS patients of about $50 \%$ [4, 19]. In contrast there are also authors noticing lower percentage of spontaneous puberty in this group of patients [23-25]. Undoubtedly recognition of non-full-blown forms of TS will be growing thanks to the availability of karyotyping, so it may reveal noticeably increased prevalence of spontaneous puberty.

Correlation between karyotype and ovarian function in TS patients has been widely discussed and many authors stated that monosomic TS patients $(45, X)$ are less likely to develop spontaneous puberty than patients with non-45,X karyotype $[4,15,19,21,23]$. Also in our study we observed that patients with non-monosomic karyotype are more likely to start puberty spontaneously than monosomic ones (14/23 61\% vs. 2/12 $16 \%)$. Nevertheless, definitive prediction of the occurrence of spontaneous puberty on the basis of karyotype is not possible. Therefore, there is no reason to wait longer than until 11-12 years of age for the first symptoms of puberty in non-45, $X$ karyotype TS girls [19].

Diagnosis of hypergonadotropic hypogonadism in adult post-menstrual women is defined as FSH level above $40 \mu \mathrm{lU} / \mathrm{ml}$.
In prepubertal children there are no specific guidelines for predicting hypogonadism, although some authors suggested limit of $\mathrm{FSH}(6.7 \mathrm{mlU} / \mathrm{ml}$ and $10 \mathrm{mlU} / \mathrm{ml}$ respectively) above which spontaneous puberty is less probable $[18,19]$.

In big cross-sectional study Visser et al. found negative correlation between $\mathrm{FSH}$ and $\mathrm{AMH}$ as well as between $\mathrm{LH}$ and $\mathrm{AMH}$. For the subgroup of girls before the age of 12 with $\mathrm{FSH}$ level $>10 \mathrm{mlU} / \mathrm{ml}$ the odds of measurable AMH was 19 times lower. Strong relationship was observed for measurable serum $\mathrm{AMH}$ and signs of spontaneous puberty [4]. The chance of spontaneous pubertal onset was increased 19 times if $\mathrm{AMH}$ was detectable [4]. It was also showed by Lunding et al. that any of girls with $\mathrm{AMH}<4 \mathrm{pmol} / \mathrm{l}$ entered puberty spontaneously [26]. In Hagen's et al. [15] longitudinal study ovarian failure was predicted in all patients with exclusively undetectable inhibin B.

In our study we also found significantly lower concentration of $\mathrm{FSH}$ and higher $\mathrm{AMH}$ and inhibin $\mathrm{B}$ levels in patients with spontaneous puberty. Interestingly in three SP patients without elevated FSH AMH and inhibin B concentrations were zero. This stays in compliance with Hagen's and Kalsey's observations that decline in serum $\mathrm{AMH}$ levels precedes the changes in another markers for ovarian reserve (FSH, estradiol and inhibin B) [21, 22].

Limitation of our study may be observation, that $37 \%$ of healthy girls have undetectable inhibin B levels [27]. Another weak point of our study may be also the fact that we used cutoff age of 12 when about $75-90 \%$ of TS girls enter puberty. At this age, according to the present guidelines induction of puberty is usually started. Nevertheless, some of the patients might enter spontaneous puberty later [28-31]. Also about 50\% of TS patents who entered puberty spontaneously would not be able to complete puberty so longitudinal monitoring of puberty and $\mathrm{AMH}$ and Inhibin B levels would be needed [32]. What is more in our study we did not differentiate patients according to growth hormone treatment whilst Visser et al. claimed that $\mathrm{GH}$ therapy increases the odds of having measurable $\mathrm{AMH}$ in TS so this aspect also needs further examination [4].

Despite these limitations, results of the study provide next argument supporting consideration of monitoring $\mathrm{AMH}$ and inhibin B levels to predict spontaneous puberty in TS patients and start estrogen replacement in most suitable moment. Further investigations in this field are needed for development of better standards of comprehensive care for patients with TS.

\section{Conclusions}

$\mathrm{AMH}$ and inhibin $\mathrm{B}$ assessment may be a valuable complement to the diagnosis of ovarian function in patients with TS. Low levels of these parameters may indicate a risk of ovarian failure even in patients with spontaneous puberty and without hypergonadotropic hypogonadism. 


\section{References}

1. Weiss L. Additional evidence of gradual loss of germ cells in the pathogenesis of streak ovaries in Turner's syndrome. J Med Genet 1971; 8: 540-544. doi: 10.1136/jmg.8.4.540

2. Reynaud K, Cortvrindt R, Verlinde F, et al. Number of ovarian follicles in human fetuses with the 45,X karyotype. Fertil Steril 2004; 81: 1112-1119. doi: 10.1016/j.fertnstert.2003.12.011

3. Anderson RA, Nelson SM, Wallace WH. Measuring anti-Müllerian hormone for the assessment of ovarian reserve: when and for whom is it indicated? Maturitas 2012; 71: 28-33. doi: 10.1016/j. maturitas.2011.11.008

4. Visser JA, Hokken-Koelega AC, Zandwijken GR, et al. Anti-Müllerian hormone levels in girls and adolescents with Turner syndrome are related to karyotype, pubertal development and growth hormone treatment. Hum Reprod 2013; 28: 1899-1907. doi: 10.1093/ humrep/det089

5. Hreinsson JG, Otala M, Fridström M, et al. Follicles are found in the ovaries of adolescent girls with Turner's syndrome. J Clin Endocrinol Metab 2002; 87: 3618-3623. doi: 10.1210/jcem.87.8.8753

6. Gravholt $\mathrm{CH}$, Andersen NH, Conway GS, et al. Clinical practice guidelines for the care of girls and women with Turner syndrome: proceedings from the 2016 Cincinnati International Turner Syndrome Meeting. Eur J Endocrinol 2017; 177: G1-G70. doi: 10.1530/EJE-17-0430

7. Charmian A, Quigley CA, Wan X, et al. Effects of Low-Dose Estrogen Replacement During Childhood on Pubertal Development and Gonadotropin Concentrations in Patients With Turner Syndrome: Results of a Randomized, Double-Blind, Placebo-Controlled Clinical Trial. J Clin Endocrinol Metab 2014; 99: E1754-E1764. doi: 10.1210/jc.2013-4518

8. Ross JL, Quigley CA, Cao D, et al. Growth hormone plus childhood low-dose estrogen in Turner's syndrome. N Engl J Med 2011; 364: 1230-1242. doi: 10.1056/NEJMoa1005669.

9. Kodama M, Komura H, Kodama T, et al. Estrogen therapy initiated at an eary age increases bone mineral density in Turner syndrome patients. Endocr J 2012; 59: 153-159. doi: 10.1507/endocrj.ej11-0267

10. Nakamura T, Tsuburai T, Tokinaga A, et al. Efficacy of estrogen replacement therapy (ERT) on uterine growth and acquisition of bone mass in patients with Turner syndrome. Endocrine J 2015; 62 : 965-970. doi: 10.1507/endocrj.EJ15-0172

11. Carel JC, Elie C, Ecosse E, et al. Self-esteem and social adjustment in young women with Turner syndrome-influence of pubertal management and sexuality: population-based cohort study. J Clin Endocrinol Metab 2006; 91: 2972-2979. doi: 10.1210/jc.2005-2652

12. Ross JL, McCauley E, Roeltgen D, et al. Self-concept and behavior in adolescent girls with Turner syndrome: potential estrogen effects. J Clin Endocrinol Metab 1996; 81: 926-931. doi: 10.1210/ jcem.81.3.8772552

13. Brooks-Gunn J, Warren MP. The psychological significance of secondary sexual characteristics in nine- to eleven-year-old girls. Child Dev 1988; 59: 1061-1069. doi: 10.1111/j.1467-8624.1988.tb03258.x

14. Ruszala A, Wojcik M, Zygmunt-Gorska A, et al. Prepubertal ultralow-dose estrogen therapy is associated with healthier lipid profile than conventional estrogen replacement for pubertal induction in adolescent girls with Turner syndrome: preliminary results. J Endocrinol Invest 2017; 40: 875-879. doi: 10.1007/s40618-017-0665-3
15. Hagen CP, Main KM, Kjaergaard S, et al. FSH, LH, inhibin B and estradiol levels in Turner syndrome depend on age and karyotype: longitudinal study of 70 Turner girls with or without spontaneous puberty. Hum Reprod 2010; 25: 3134-3141. doi: 10.1093/humrep/ deq291

16. Conte FA, Grumbach MM, Kaplan SL. A diphasic pattern of gonadotropin secretion in patients with the syndrome of gonadal dysgenesis. J Clin Endocrinol Metab 1975; 40: 670-674. doi: 10.1210/ jcem-40-4-670

17. Chrysis D, Spiliotis BE, Stene M, et al. Gonadotropin secretion in girls with turner syndrome measured by an ultrasensitive immunochemiluminometric assay. Horm Res 2006; 65: 261-266. doi: $10.1159 / 000092516$

18. Aso K, Koto S, Higuchi A, et al. Serum FSH level below $10 \mathrm{mlU} / \mathrm{mL}$ at twelve years old is an index of spontaneous and cyclical menstruation in Turner syndrome. Endocr J 2010; 57: 909-913. doi: 10.1507/endocrj.k10e-092

19. Hankus M, Soltysik K, Szeliga K, et al. Prediction of Spontaneous Puberty in Turner Syndrome Based on Mid-Childhood Gonadotropin Concentrations, Karyotype, and Ovary Visualization: A Longitudinal Study. Horm Res Paediatr 2018; 89: 90-97. doi: 10.1159/000485321

20. Nardo LG, Christodoulou D, Gould D, et al. Anti-Müllerian hormone levels and antral follicle count in women enrolled in in vitro fertilization cycles: relationship to lifestyle factors, chronological age and reproductive history. Gynecol Endocrinol 2007; 23: 486493. doi: 10.1080/09513590701532815

21. Hagen CP, Aksglaede L, Sørensen K, et al. Serum levels of anti-Müllerian hormone as a marker of ovarian function in 926 healthy females from birth to adulthood and in 172 Turner syndrome patients. J Clin Endocrinol Metab 2010; 95: 5003-5010. doi: 10.1210/jc.2010-0930

22. Kelsey TW, Anderson RA, Wright $P$, et al. Data-driven assessment of the human ovarian reserve. Mol Hum Reprod 2012; 18: 79-87. doi: 10.1093/molehr/gar059

23. Pasquino AM, Passeri F, Pucarelli I, et al. Spontaneous pubertal development in Turner's syndrome. Italian Study Group for Turner's Syndrome. J Clin Endocrinol Metab 1997; 82: 1810-1813. doi: 10.1210/jcem.82.6.3970

24. Negreiros LP, Bolina ER, Guimarães MM. Pubertal development profile in patients with Turner syndrome. J Pediatr Endocrinol Metab 2014; 27: 845-849. doi: 10.1515/jpem-2013-0256

25. Hamza RT, Mira MF, Hamed Al, et al. Anti-Müllerian hormone levels in patients with turner syndrome: Relation to karyotype, spontaneous puberty, and replacement therapy. Am J Med Genet A 2018; 176: 1929-1934. doi: 10.1002/ajmg.a.40473

26. Lunding SA, Aksglaede L, Anderson RA, et al. AMH as Predictor of Premature Ovarian Insufficiency: A Longitudinal Study of 120 Turner Syndrome Patients. J Clin Endocrinol Metab 2015; 100: E1030E1038. doi: 10.1210/jc.2015-1621

27. Gravholt CH, Naeraa RW, Andersson AM, et al. Inhibin A and B in adolescents and young adults with Turner's syndrome and no sign of spontaneous puberty. Hum Reprod 2002; 17: 2049-2053. doi: 10.1093/humrep/17.8.2049

28. Massa G, Heinrichs C, Verlinde S, et al. Late or delayed induced or spontaneous puberty in girls with Turner syndrome treated with growth hormone does not affect final height. J Clin Endocrinol Metab 2003; 88: 4168-4174. doi: 10.1210/jc.2002-022040 
29. Martin DD, Schweizer R, Schwarze CP, et al. The early dehydroepiandrosterone sulfate rise of adrenarche and the delay of pubarche indicate primary ovarian failure in Turner syndrome. J Clin Endocrinol Metab 2004; 89: 1164-1168. doi: 10.1210/jc.2003-031700

30. Schweizer R, Ranke MB, Binder G, et al. Experience with growth hormone therapy in Turner syndrome in a single centre: low total height gain, no further gains after puberty onset and unchanged body proportions. Horm Res 2000; 53: 228-238. doi: 10.1159/000023572
31. Ranke MB, Lindberg A, Ferrández Longás A, et al. Major determinants of height development in Turner syndrome (TS) patients treated with GH: analysis of 987 patients from KIGS. Pediatr Res 2007; 61: 105-110. doi: 10.1203/01.pdr.0000250039.42000.c9

32. Reindollar RH. Turner syndrome: contemporary thoughts and reproductive issues. Semin Reprod Med 2011; 29: 342-352. doi: 10.1055/s-0031-1280919 